\title{
Qualities of Servant Leaders among Catholic Schools: A Cross- sectional Analysis
}

\author{
Rev. Fr. Raymann G. Catindig ${ }^{1}$ and Prof. Dr. David Cababaro Bueno ${ }^{1}$ \\ ${ }^{1}$ Doctorate Student at Columban College, and a School Director of a Catholic School in Zambales \\ ${ }^{2}$ Dean of Graduate, and Colleges of Arts, Sciences and Education at Columban College, Inc., Olongapo City, \\ Zambales, Philippines
}

\begin{abstract}
This study aimed to analyze the servant leadership (SL) qualities among the administrators of the Catholic schools in the Diocese of Iba. The descriptive-survey design was used with the aid of surveyquestionnaire. The data were treated using Mean, $t$-Test, and ANOVA. The Catholic school administrators (CSA) educational leaders of character-oriented, but not totally concerned with developing human resources, achieving productivity and success, and increasing the efficiency of the organization as viewed by their teachers. They overrated their quality compared to the ratings given by the teachers. Significant variations on the SL qualities of CSA across schools are prominent with respect to teambuilding, modeling, shared decision-making, leading, developing others, goal-setting and servanthood. No significant variations on the SL qualities of CSA across schools are revealed relative to integrity, humility, caring for others, empowering others and visioning. The proposed Multidimensional Model of SL maybe translated to a more popular medium for its future application among Catholic schools in the Philippines
\end{abstract}

Keywords: Education, servant leadership, administrators, Catholic schools, cross-sectional design, Zambales

\section{Introduction}

Servant is defined as a person working in the service of another; one who expresses submission, recognizance, or debt to another' and a person who labors or exerts himself for the benefit of another, his master or employer, a subordinate helper. A leader on the other hand is defined as, one who is in charge or in command of others, a person who is the head of organizers or is in charge (of something); and a guiding or directing head, as of an army, movement, or political group. Servant and leadership are two words that are seemingly paradoxical in nature. Is it possible that one can fuse the characteristics and nature of a servant yet at the same time possess the authority and power of a leader?

Since the beginning of time, servant leadership has been manifested thru different personalities. From Lau Tzu from 600 B.C. up until today, many persons in authority applies the servant leadership philosophy for its' unyielding results and its' fulfilling benefits not just in the field of work but also in the management of an organization in a certain community. Robert Greenleaf, who is largely considered as the modern father of the servant-leadership, defines servant-leadership as: "something that begins with the natural feeling that one wants to serve first. Then conscious choice brings one to aspire to lead."

Another popular servant leader in the person of Jesus Christ describes the concept of servant leadership as: "But the greatest among you shall be your servant (Matthew 2:11); the one who is the greatest among you must become like the youngest, and the leader likes the servant (Luke 22:26). It is in this context that heads of Catholic academic institutions are expected to be servant leaders in their organizations. Whether they are priests of lay administrators there must be "something in them that begins with the feeling that they want to serve which brings them to aspire to lead". The servant-leader is servant first. It begins with the natural feeling that one wants to serve. Then conscious choice brings one to aspire to lead. The best test is: do those served grow as persons: do they, while being served, become healthier, wiser, freer, more autonomous, more likely themselves to become servants? And, what is the effect on the least privileged in society; will they benefit, or, at least, not be further deprived? (Greenleaf, 2002). 
Catholic schools are a ministry of the parish. Although Catholic school boards have a significant role in the decision-making of Catholic schools, Catholic school principals are the primary decision-makers within a school. If principals have common role expectations they will likely be more effective leaders in their community. The language and characteristics of servant leadership are the most appropriate leadership style for Catholic school leaders (Schafer, 2005). The doctrines and teachings of the Catholic Church encourage members of the Catholic community to live the principles of servant leadership.

The concept of servant leadership occurs in the Bible through examples from Moses to Jesus. The word servant is in the Bible almost 1,000 times. Scholars, contemporary authors, and researchers have cited biblical references to support servant leadership (Blanchard \& Hodges, 2002). Jesus, considered by some scholars to be the greatest leader to have lived (Kubicek, 2005), presented a model of leadership focusing on God, not the leader. Jesus exemplified leadership as care, love, and submission rather than strength, might, and power.

In a document from the United States Conference of Catholic Bishops (1972), To Teach As Jesus Did, the bishops promoted the concept that it is the responsibility of the Christian community to follow the example of Jesus.

The bishops stated, "This community is based not on force or accident of geographic location or even on deeper ties of ethnic origin, but on the life of the Spirit which unites its members in a unique fellowship so intimate that Paul likens it to a body of which each individual is part and Jesus Himself is the Head. (sec. 22)

Jesus' life and teachings exemplified the perfect servant leader (Blanchard \& Hodges, 2002). Jesus did not lead from behind, but rather he stood out front, even in the face of great adversity. He had a vision of what he had to do, and probably knew there was a short time to complete his tasks. Ultimately, the essence of Jesus' message was simple; he showed by example (Spears, 1998). "Jesus washing his disciples' feet is a dramatic example of His service and humility to people".

The characteristics of servant leaders, as defined by Spears (1998), listening, empathy, healing, awareness, persuasion, conceptualization, foresight, stewardship, commitment to the growth of people, and building community, are what one would expect in a Catholic school (Schafer, 2005). The Church's philosophy on education aligns with the principles of servant leadership as noted in a document from the Vatican: the Congregation for Catholic Education (CCE; 1998), stated, "A Catholic school is not simply a place where lessons are taught, it is a center that has an operative educational philosophy, attentive to the needs of today's youth and illuminated by the Gospel message" (sec. 22).

Based from the foregoing claims, the researcher considered the qualities of servant leadership (Page \& Wong (2000) as the basis of analysis particularly among Catholic school administrators in the Diocese of Iba, Zambales.

\section{Objective Of The Study}

This study aimed to analyze the servant leadership qualities among the administrators of the Catholic schools in the Diocese of Iba. Specifically, it sought to analyzed (1) the servant leadership qualities of the school administrators (Lay and Priest) among Catholic; (2) the significant difference between the assessment of the teachers and the self-assessment of the school administrators with regards to their servant leadership qualities; and (3) the significant variations on the assessments on servant leadership qualities among administrators of Catholic Schools.

\section{Methodology}

This study utilized the descriptive-cross-sectional design in determining the servant leadership qualities of Catholic school administrators. This method is to describe systematically the facts and characteristics of a given population or area of interest, factually and accurately.

The entire population of this study was those in the administrative level among member-schools of ACSDI. 
The research was solely for the principal, treasurer and directors of all ACSDI Basic Education Institutions. There were a total of 13 principals, 13 treasurers, and 13 directors subjected in the study.

This study used survey-questionnaire as main instrument used in data-gathering. The questionnaire was designed to assess several servant leadership characteristics of Catholic school administrators. Wong and Page (2000) identified twelve attributes of servant leadership to be integrity, humility, servanthood, caring for others, empowering others, developing others, visioning, goal setting, leading, modeling, team building, and shared decision-making. The servant leadership qualities of the administrators were based on the attributes adapted from Wong and Page.

It used scales to indicate the level of agreement or disagreement with each of the descriptors of servant leadership: (5) Strongly Agree; (4) Agree; (3) Moderately Agree; (2) Disagree; and (1) Strongly Disagree. Since the instrument was adapted, there was no more major validation done. Page and Wong conducted a pilot study in which the alpha2 values for each subscale were calculated, as well as the total assessment score. The alpha coefficients Page and Wong calculated for the 12 categories were integrity (.9o), humility (.86), servanthood (.76), caring for others (.71), empowering others (.77), developing others (.92), visioning (.97), goal-setting (.77), leading (.84), modeling (.76), team building (.82), and shared decision-making (.80). An alpha coefficient of 0.70 or higher indicates acceptable levels of internal reliability, which means that all the items in the same category measure the same attribute. Thus, the instrument validity and reliability were established.

Permission and endorsement were obtained from the ACSDI Chairman and Directors/Presidents of the participating schools. The participants were informed of the nature and procedures of the study. They were informed that their participation was voluntary and they were given the right to withdraw from the study at any time. Every effort was made to ensure the confidentiality and anonymity of the participants, including removal of names and details from quotes and descriptions that might reveal the identity of an individual, and by using alphabetical labels when quoting the participants' statements. After the completion of the interviews, participants were given the opportunity to review their responses and to make any changes to their statements. Thus, there were no problems encountered by the researcher in the distribution and retrieval of the instrument.

The data gathered were organized and processed through the Statistical Package for Social Sciences (SPSS). The statistical tools such as Mean, t-Test and ANOVA were employed.

\section{Results And Discussion}

1. Servant Leadership Qualities of the School Administrators. The servant leadership qualities are in relation to integrity, humility, servanthood, caring for others, empowering others, developing others, visioning, goal setting, leading, modeling, team-building, and shared decision-making.

1.1 Integrity. Both the group of Catholic school administrators (CSA) and Catholic school teachers (CST) strongly agree that administrators are genuine and candid with people, willing to be vulnerable in order to be transparent and authentic; practice what they preach; concern about doing what is right; do not use manipulation or deception to achieve goals; promote tolerance, kindness, and honesty in the work place; want to build trust through honesty and empathy; and do not compromise ethical principles in order to achieve success. Thus, the overall assessments are 4.77 (SCA), and 4.33 (CST), which means strongly agree. The findings imply that the construct of trust can be seen as both moderating and reciprocal of a servant leadership style (Greenleaf, 1977, Joseph \& Winston, 2005). Some leadership researchers go so far as to say that simply cannot lead without trust, as it is the central issue in human relationships (Kouzes \& Posner, 2007). Psychologists have long held trust as the basis for healthy relationships, and the absence of trust as detrimental to emotional health. Trust and integrity in the leaders of an organization is no less important and should be viewed as the most important aspect of meeting employee needs. Thus, an educational leader must follow a professional code of conduct that includes an ethical code

1.2 Humility. As revealed, both the group of Catholic school administrators (CSA) and Catholic school teachers (CST) strongly agree that the school administrators are always prepare to step aside if someone is more 
qualified to do the job; work behind the scene and let others take the credit; if people criticize them, they do not take it personally and try to learn something from it; do not seek recognition or rewards in serving other; learn from subordinates whom they serve; readily admit when they are wrong; celebrate a colleague's accomplishments than their own; and regularly acknowledge their dependency on others. However, it appears that the teachers are totally convinced that the school administrators confess their limitations and weaknesses. The overall assessments are 4.44 (SCA), and 4.26 (CST), which means strongly agree. According to Collins (2001), organizations do not only need to be good today in order to survive, but great, and a fundamental ability in building great oraganizations is displaying humility as well as strength. Interestingly, humility is one of the main characteristics of the emerging people-centered leadership theory, servant leadership (Greenleaf, 1970; Dierendonck \& Nuijten, 2011 as cited in Stefansdottir, 2013). Humility is an attitude and acknowledgment by the servant leader that they are neither omniscient nor omnipotent, and that employee's may have more knowledge and experience. Ferch (2005) argued, "one of the defining characteristics of human nature is the ability to discern one's own faults, to be broken as the result of such faults, and in response to seek a meaningful change". For servant leaders in organizations dependent on knowledge workers, this is especially important as it is highly probable that employees do indeed know more about their specialization than anyone else inside the company. Indeed, humility is also about modesty and it is for this reason that a servant leader retreats into the background when a task has been fully accomplished.

1.3 Servanthood. Servanthood among Catholic school administrators (CSA) as viewed by themselves and by the Catholic school teachers (CST) is characterized by the following: (1) finding enjoyment in serving others in whatever role or capacity; (2) willingness to maintain a servant's heart, even though some people may take advantage of my leadership style; (3) willingness to make personal sacrifices in serving others; (4) willingness in serving others; (5) willingness to endure opposition and unfair criticisms; (6) having a heart to serve others; (7) believing that leadership is more of a responsibility than a position; (8) seeking to serve rather than be served; (9) working for the best interests of others rather than self; (10) finding better ways of serving others and making them successful; and (11) serving others without regard to their gender, race, ethnicity, religion or position. The overall assessments on servanthood among school administrators are 4.72 (SCA), and 4.29 (CST), which means strongly agree. The findings of the study are in support the virtue of service which is at the core of the servant leadership model (Patterson, 2003). Servant leaders imbue the meaning of and reinforce the importance of serving others within and outside the organization through their behavior, which provides crucial cues that serving others is a distinctive characteristic of the organization (Zhang et al, 2012). According to Spears (2004) a great leader is first experienced as a servant by others including employees, customers and community as the number one priority.

1.4 Caring for others. Caring for others as viewed by Catholic school administrators (CSA) themselves and by the Catholic school teachers (CST) is characterized by genuine caring for the welfare of people working with them; seeking first to understand than to be understood; believing that caring about people brings out the best in them; and extending grace and forgiveness to others even when they do not reciprocate. However, the CST are not really convinced that the CSAs are trying to help others without pampering or spoiling them; many people come to them with their problems, because they listen to them with empathy; making themselves available to all workers/colleagues; and listening actively and receptively to what others have to say. The overall assessments on caring for others as indicator of servant leadership among school administrators are 4.66 (SCA), and 4.21(CST), which means strongly agree. In the light of the finding of the present study, another quality of the servant leader is the desire and ability to listen with the intention of understanding the other person (Greenleaf, 1970). In discussing the importance of listening, Greenleaf detailed how to develop this trait. He stated "that a non-servant who wants to be a servant might become a natural servant through a long arduous discipline of learning to listen, a discipline sufficiently sustained that the automatic response to any problem is to listen first". Lubin (2001) concurred that successful servant leaders "begin by making a deep commitment to listening, not only to others but to their own inner voice as well. Thus, the researcher believes that essential to the growth of the leader is the condition to have quiet reflective time for deeper understanding". 
1.5 Empowering others. Empowering others as viewed by Catholic school administrators (CSA) themselves and by the Catholic school teachers (CST) is distinguished by consistently encouraging others to take initiative. However, it seems that the CSTs are not totally convinced that the CSAs are willing to risk mistakes by empowering others to "carry the ball"; granting all the workers a fair amount of responsibility and latitude in carrying out their tasks; and continuously appreciating, recognizing and encouraging the work of others. Thus, the overall assessments are 4.43 (SCA), strongly agree; and 4.18 (CST), agree. Empowerment is a major factor in servant leadership and should be one of its primary focus (Russell \& Stone, 2002). Patterson (2003) concurs by stating that empowering people, with the best interest of those served in mind is at the heart of servant leadership. She further asserts that it is entrusting power to others and really giving it away. It is letting people to do their jobs by enabling them to learn, grow and progress and as such it means allowing for self-direction and freedom to fail and this multiplies the follower's strengths and trust (Patterson, 2003). An empowering and developing person is about giving people in the workplace responsibility for their own actions. Through empowerment, the servant leader acknowledges the talents and strengths of employees.

1.6 Developing others. As viewed by Catholic school administrators (CSA) themselves and by the Catholic school teachers (CST), developing others is well-known among Catholic schools when others make a mistake, CSAs are very forgiving, and helpful for them to learn from their mistakes. However, it appears for the CSTs to be not totally aware that the CSAs are always looking for hidden talents among them; having great satisfaction in bringing out the best in others; investing considerable time and energy equipping others, and in helping others overcome their weaknesses and develop their potential; developing potential leaders who will surpass them in the organization. In general, the CSTs are not totally convinced that the leadership of Catholic school administrators is contributing to their employees/ colleague's personal growth. Thus, the overall assessments are 4.47 (SCA), strongly agree; and 4.17 (CST), agree. In discussing the importance of being committed to the growth of people, Taylor (2002) stated, an essential characteristic of servant leadership is a belief that people have intrinsic value beyond their tangible contributions as workers. This belief motivates the servant leader to develop a deep commitment to the growth of each and every individual within his or her organization. This commitment involves a tremendous responsibility to do everything within the leader's power to nurture both the professional and the personal growth of his or her employees. In a practical sense, TaylorGillham (1998) claimed that this commitment to the growth of people takes place in the form of "making available funds for personal and professional development, taking a personal interest in ideas and suggestions from everyone, encouraging worker involvement in decision-making, and actively assisting laid-off workers to find other employment". The researchers of the present study believes that removing obstacles that prevent people from effectively doing their jobs, a servant leader helps each individual realize his or her full potential. The servant leader is committed to the growth of others and recognizes that individuals are more valuable than just what they contribute to their job.

1.7 Visioning. Both the group of Catholic school administrators (CSA) and Catholic school teachers (CST) strongly agree that CSAs leadership is based on a strong sense of mission; and have a sense of a higher calling. However, the CSTs are not totally convinced that CSAs are driven by values that transcend self-interests and material success; firmly believing that every organization needs a higher purpose; able to articulate a clear sense of purpose and direction for my organization's future; want the organization to become or do for society; able to inspire others with their enthusiasm and confidence for what can be accomplished; and always directed towards the accomplishment of a vision and mission. Thus, the overall assessments are 4.62 (SCA), strongly agree; and 4.15 (CST), agree. The researchers of the present study believes that visioning servant leader behavior entails having foresight. Hale and Fields (2007) suggest foresight needs to be combined with the ability to communicate the vision to and influence teachers in and developing a shared vision for an organization. In the visionary role, leaders are expected to define the direction of the organization and they need to communicate what the organization stands for and how organizational values encompass the individual values of its members (Blanchard, 2000). When it comes to vision and values, the leader has to say it over and over and over again until people get it right (De Pree, 1997). 
1.8 Goal setting. The group of Catholic school administrators (CSA) strongly agree that they are very focused and disciplined at work; able to motivate others to achieve beyond their own expectations in getting a job done; set clear and realistic goals; more concerned about getting the job done than protecting my "territory"; demand a high level of productivity from myself as well as from others; and more interested in results than activities or programs. However, the group of Catholic school teachers (CST) viewed these qualities lower as compared to the views of the CSAs. Thus, the overall assessments are 4.52 (SCA), strongly agree; and 4.04 (CST), agree. From an academic standpoint, goal setting theory enjoys a long and rich history. The first empirical studies on the topic emerged from the work of Cecil Alec Mace (Carsona, Carsona, \& Heady, 1994). Thus, the researchers believe that goals should clarify the institutional vision and lay out realistic goals and objectives consistent with that vision. If the goals incorporate the work being done by the development, admissions, and other administrative offices, then those results will be given directly to the head for addition to the goals.

1.9 Leading. The group of Catholic school administrators (CSA) strongly agrees that they inspire others to strive for excellence; usually come up with solutions accepted by others as helpful and effective; widely consulted others and carefully considering all the options, and do not hesitate in making difficult decisions; try to match people with their jobs in order to optimize productivity; communicate ideas to others effectively; have a good understanding of what is happening inside the organization; share their power with others, but do not abdicate their authority and responsibility; have the ability to move the group forward and get things done; know how to work with and around difficult people to achieve results; take proactive actions rather than waiting for events to happen. However, the group of Catholic school teachers (CST) viewed these qualities lower as compared to the views of the CSAs. Thus, the overall assessments are 4.51 (SCA), strongly agree; and 4.03 (CST), agree. Day et al (2000) conclude that, "Research findings from diverse countries and different school contexts have revealed the powerful impact of leadership processes related to school effectiveness and improvement. Thus, the researchers of the present study strongly believes that successful CSAs should be turned out to be men and women with varied professional backgrounds who worked in collaboration with teacher and showed respect for the teaching culture.

1.10 Modeling. The group of Catholic school administrators (CSA) strongly agrees that they lead by example; often demonstrate for others how to make decisions and solve problems; show their group how to facilitate the process of group success; model for others how everyone can improve the process of production; never ask anyone to do what they unwilling to do themselves; and make it a priority to develop relations with those who model servant leadership. However, the group of Catholic school teachers (CST) viewed these qualities lower as compared to the views of the CSAs. Thus, the overall assessments are 4.41 (SCA), strongly agree; and 4.03 (CST), agree. Modeling in the form of a visible personal example is an important component of servant leadership (Russell \& Stone, 2002). Modeling is the principle way through which a leader can influence the followers. Leaders model the way through personal example and dedicated execution. Modeling provides an example and demonstrates the behavior that the leader is seeking from others. Servant leaders model examples that can be emulated by others. Authentic leaders model what matters and are willing to practice what they preach when it comes to expected organizational behavior. Modeling what matters is the primary and most effective way to communicate the organization's mission, values, and ethos and that action communicates much more loudly than words when it comes to organizational values.

1.11 Team-building. The group of Catholic school administrators (CSA) strongly agrees that they are willing to sacrifice personal benefits to promote group harmony and team success; evaluating and deploying team members based solely on their performance and capacity for serving others; encouraging cooperation rather than competing through the group; not playing favorites, and trying to treat everyone with dignity and respect; regularly celebrating special occasions and events to foster a group spirit; usually finding creative and constructive ways to resolve conflicts; valuing everyone on the team; transforming an ordinary team into a winning team; actively seeking ways to utilize people's differences as a contribution to the group; developing the 
team by praising their accomplishments and working around their deficiencies; and enlivening team spirit by communicating enthusiastically and confidently. However, the group of Catholic school teachers (CST) views these characteristics lower as compared to the views of the CSAs. Thus, the overall assessments are 4.59 (SCA), strongly agree; and 4.04 (CST), agree. This team-building cultivates the development of other servant leaders who will similarly "go forth to build community". Page and Wong (2000) reported a further benefit of teambuilding by stating, in servant-leadership there is no such thing as "just a groundskeeper" or "just a secretary". Everyone is part of a team working to the same end in which people play different roles at different times, according to their expertise and assignment, rather than their position or title.

1.12 Shared decision-making. The group of Catholic school administrators (CSA) strongly agrees that they are willing to share their power and authority with others; welcoming ideas and input from others, including critics and detractors; exercising leadership through personal influence and persuasion rather than power; removing all organizational barriers so that others can freely, participate in decision-making; encouraging flexibility and ongoing exchange of information within the organization; willing to have their ideas challenged; placing the greatest amount of decision-making in the hands of those most affected by the decision; and sharing information at all levels in the organization. However, the group of Catholic school teachers (CST) views these characteristics lower as compared to the views of the CSAs. Thus, the overall assessments are 4.62 (SCA), strongly agree; and 4.03 (CST), agree. Servant leadership creates high-performing organizations because it supports shared power and high involvement throughout the organization. Blanchard (2007) stated that servant leadership not just another management technique; servant leadership is a way of life. Servant leaders work to establish the vision and values upfront and work to bring out the best in those whom the leaders serve. They know that when all are involved with decisions that affect their lives they are happier and have a greater sense of ownership and commitment. Schools with a culture of shared decision-making that focus on student achievement, collaboration, and open communication are likely to produce learning communities that enhance school effectiveness, including student achievement. Teacher empowerment does not take place on its own and cannot be mandated as part of an initiative. Schools that have an administrator's leadership that is collegial and supportive create an environment where teacher empowerment can grow and thrive. Growth is not measured by the power that the school leader holds but rather by the leader's ability to empower others.

3. Difference Between the Assessment of the Teachers and the Self-assessment of the School Administrators with Regards to their Servant Leadership Qualities. Table 1 shows the t-values for the test of significant difference on the assessments of the two group of respondents.

Table I. Differences on the Assessments of the Servant Leadership Qualities of Administrators

\begin{tabular}{ccccc}
\hline Areas & $\begin{array}{c}\mathbf{t}- \\
\text { Value }\end{array}$ & $\begin{array}{c}\text { P- } \\
\text { Value }\end{array}$ & $\begin{array}{c}\text { Decision } \\
(\boldsymbol{\alpha}=\mathbf{0 . 0 5})\end{array}$ & Interpretation \\
\hline Integrity & 5.623 & 0.000 & Reject Ho & Significant \\
\hline Humility & 7.568 & 0.000 & Reject Ho & Significant \\
\hline Servanthood & 11.187 & 0.000 & Reject Ho & Significant \\
\hline Caring for Others & 8.726 & 0.000 & Reject Ho & Significant \\
\hline $\begin{array}{c}\text { Empowering } \\
\text { Others }\end{array}$ & 4.097 & 0.003 & Reject Ho & Significant \\
\hline Developing Others & 8.638 & 0.000 & Reject Ho & Significant \\
\hline Visioning & 8.829 & 0.000 & Reject Ho & Significant \\
\hline Goal-Setting & 7.440 & 0.000 & Reject Ho & Significant \\
\hline Leading & 15.491 & 0.000 & Reject Ho & Significant \\
\hline Modeling & 4.910 & 0.001 & Reject Ho & Significant \\
\hline Team Building & 13.177 & 0.000 & Reject Ho & Significant \\
\hline $\begin{array}{c}\text { Shared Decision- } \\
\text { Making }\end{array}$ & 20.220 & 0.000 & Reject Ho & Significant \\
\hline
\end{tabular}

The overall mean assessment of the CSAs is quite higher than the mean assessment of the CSTs with regards to the attributes of servant leadership among Catholic schools in the Diocese of Iba. This accounts for the positive value of $t$. All the computed t-values are significant within 0.05 level. These are 5.623 (integrity); 7.568 (humility); 11.187 (servanthood); 8.726 (caring for others); 4.097 (empowering others); 8.638 (developing others); 8.829 (visioning); 7.440 (goal-setting); 15.491 (leading); 4.910 (modeling); 13.177 (team-building); and 
20.220 (shared decision-making). Thus, the null hypothesis is rejected in all variables. This only tells that the perception of the CSAs as to their servant leadership qualities is significantly different (higher) from the perception of the CSTs. The administrators overrated their quality which is far above the ratings from the teachers.

4. Variations on the Assessments Regarding Servant Leadership Qualities among Administrators. Table 2 shows the computed F-values to test the significant variations on the assessments on servant leadership qualities among administrators of Catholic Schools in the Diocese of Iba. It shows that there are significant variations on the responses across schools in terms of servant leadership qualities of teambuilding, modeling, shared decision-making, leading, developing others, goal-setting and servanthood with computed F-values of $12.165,10.128,8.547,4.211,3.997,3.873$ and 3.642, respectively. These values are significant within 0.05 level, thus the null hypothesis is rejected. On the other hand, there are no significant variations on the responses across schools in terms of servant leadership qualities of integrity, humility, caring for others, empowering others and visioning with computed F-values of $0.894,1.953,1.875,1.354$ and 1.233 , respectively. These are not significant using 95\% confidence level. The null hypothesis is accepted.

Table II. Variations on the Servant Leadership Qualities among Administrators Across Schools

\begin{tabular}{ccccc}
\hline Areas & $\begin{array}{c}\text { F- } \\
\text { Value }\end{array}$ & $\begin{array}{c}\text { P- } \\
\text { Value }\end{array}$ & $\begin{array}{c}\text { Decision } \\
(\boldsymbol{\alpha}=\mathbf{0 . 0 5})\end{array}$ & Interpretation \\
\hline Integrity & 0.894 & 0.642 & Accept Ho & Not Significant \\
\hline Humility & 1.953 & 0.088 & Accept Ho & Not Significant \\
\hline Servanthood & 3.642 & 0.036 & Reject Ho & Significant \\
\hline Caring for Others & 1.875 & 0.124 & Accept Ho & Not Significant \\
\hline Empowering Others & 1.354 & 0.285 & Accept Ho & Not Significant \\
\hline Developing Others & 3.997 & 0.023 & Reject Ho & Significant \\
\hline Visioning & 1.233 & 0.344 & Accept Ho & Not Significant \\
\hline Goal Setting & 3.873 & 0.028 & Reject Ho & Significant \\
\hline Leading & 4.211 & 0.015 & Reject Ho & Significant \\
\hline Modeling & 10.128 & 0.000 & Reject Ho & Significant \\
\hline Team Building & 12.165 & 0.000 & Reject Ho & Significant \\
\hline $\begin{array}{c}\text { Shared Decision- } \\
\text { Making }\end{array}$ & 8.547 & 0.000 & Reject Ho & Significant \\
\hline & & & \\
\hline
\end{tabular}

\section{Conclusions And Recommendations}

The Catholic school administrators in the Diocese of Iba are educational leaders of character-oriented, concerned with cultivating a servant's and caring attitude, focusing on the leader's values, credibility and motive. The Catholic school administrators are leaders who are not totally concerned with developing human resources, achieving productivity and success, and increasing the efficiency of the organization as viewed by their teachers. The null hypothesis is rejected in all attributes of servant leadership. The assessment of school administrators relative to their servant leadership qualities is significantly higher. Thus, the administrators overrated their quality which is far above compared to the ratings given by the teachers. Significant variations on the servant leadership qualities of administrators across Catholic schools are prominent with respect to teambuilding, modeling, shared decision-making, leading, developing others, goal-setting and servanthood. No significant variations on the servant leadership qualities of administrators across Catholic schools are revealed relative to integrity, humility, caring for others, empowering others and visioning.

The Catholic school administrators should sustain being character-oriented leader by showing integrity, humility, servants' and caring hearts. The Catholic school administrators should observe and practice at all times to become more people, task and process-oriented educational leader by focusing on the relationship with people and commitment to develop others; tasks and skills necessary for success; and ability to model and develop a flexible, efficient and open system. The Catholic school administrators, if promoted, transferred, relocated or rotated as to their job assignments, should portray and model similar team-building, decisionmaking, leading, developing others, goal-setting and servanthood practices. The Catholic school administrators should find ways sustaining their servant leadership qualities by empowering their employees and being 
visionary leader at all times. The proposed Multidimensional Model of SL maybe translated to a more popular medium for its future application among Catholic schools in the Philippines.

\section{References}

[1] Blanchard, K. (1996). "Turning the Organizational Pyramid Upside Down." In F. Hesselbein, M. Goldsmith and R. Beckhard, eds. The Leader of the Future: New Visions, Strategies, and Practices for the Next Era. San Francisco, CA: Jossey-Bass.

[2] Carsona, Carsona, \& Heady (1994). Manual for the Leadership. Minneapolis, MN: National Computer Systems.

[3] Collins, J. (2001). Built to Last: Successful Habits of Successful Companies. New York: Harper- Business.

[4] Covey, S. R. (1998). "Servant-Leadership from the Inside Out" In L. Spears, ed. Insights on Leadership: Service, Stewardship, Spirit, and Servant-Leadership. New York, NY: John Wiley.

[5] Day et al (2000). "A Model of Leadership." The Leader of the Future: New Visions, Strategies, and Practices for the Next Era. San Francisco, CA: Jossey-Bass.

https://doi.org/10.1016/S1048-9843(00)00061-8

[6] De Pree (1997). Servant-Leadership." Insights on Leadership: Service, Stewardship, Spirit, and Servant-Leadership, New York: John Wiley \& Sons, Inc.

[7] Dierendonck \& Nuijten (2011). "Leadership Theory: A Report of Progress." In C. I. Cooper \& I. Robertson, eds. International Review of Industrial and Organizational Psychology. New York: Wiley.

[8] Ferch (2005). The Holy Ground of Leadership." In L. Spears, ed. Insights on Leadership: Service, Stewardship, Spirit, and Servant-Leadership. New York, NY: John Wiley.

[9] Greanleaf, R. K. (1991). The Servant as Leader. Indianapolis: The Greenleaf Center (30).

[10] Greenleaf, R. K. (1970). The servant as leader. Indianapolis, IN: The Robert K. Greenleaf Center.

[11] Greenleaf, R. K. (2002). Servant Leadership: A Journey into the Nature of Legitimate Power and Greatness. New York, NY: Paulist Press.

[12] Greenslade, P. (1984). Leadership, Greatness and Servanthood. .Minneapolis, MN: Bethany House.

[13] Hale and Fields (2007). Leading With a Follower's Heart. Wheaton, IL: Scripture Press.

[14] Joseph \& Winston (2005). The Leader of the Future: New Strategies, and Practices for the Next Era. San Francisco, CA: Jossey-Bass.

[15] Kouzes, J. M. \& Posner, B. Z. (2007). Credibility: How Leaders Gain and Lose It, Why People Demand It. San Francisco: Jossey-Bass.

[16] Kubicek, L. (2005). Insights on Leadership: Service, Spirit, and Servant Leadership. New York, NY: John Wiley.

[17] Lubin (2001). Organizational leadership assessment. Retrieved April 27, 2004, from http://www.olagroup.com/documents/instrument.pdf

[18] Page \& Wong (2000). The Dynamics of Management Derailment. Greensboro, North Carolina: Center for Creative Leadership.

[19] Patterson (2003). High-Involvement, High-Performance Teams in Higher Education: The Impact of Leadership." In K. E. Clark, M. B. Clark, and D. P. Campbell, eds. Impact of Leadership. Greensboro, NC: Center for Creative Leadership

[20] Russell \& Stone, 2002). Leadership in a New Era: Visionary Approaches to the Biggest Crisis of our Time. San Francisco, CA: New Leaders Press.

[21] Schafer (2005).: Visionary Approaches to the Biggest Crisis of our Time. San Francisco, CA: New Leaders Press 
[22] Spears, L. C. (1998). "Servant-Leadership and the Greenleaf Legacy." In L. C. Spears, ed. Reflections on Leadership: How Robert K Greenleaf's Theory of Servant-Leadership Influenced Today's Top Management Thinkers. New York, NY: John Wiley

[23] Spears, L. C. (2004). "Introduction: Tracing the Growing Impact of Servant-Leaders" in L. C. Spears, ed. Insights on Leadership: Service, Stewardship, Spirit, and Servant-Leadership. New York, NY: John Wiley

[24] Stefansdottir (2013). Leadership Behavior, Its Description and Measurement. Columbus: Ohio State University, Bureau of Business Research.

[25] Taylor (2002). Servant leadership practices. The Community College Enterprise, 9(2), 103-113.

[26] Taylor-Gillham (1998). The perception of servant leadership characteristics and job satisfaction. Dissertation Abstracts International, 62 (03), 29-31

[27] Zhang et al, (2012). Servant of the People: The 1960s Legacy of African American Leadership. New York, NY: St. Martin's Press. 